\title{
The Effect of Calcium Canal Blocker, Verapamil, on Cell Cycle and Apoptosis in Acute Myeloid Leukemia Cancer Cell Line (HL-60)
}

\author{
Gülper NACARKAHYA ${ }^{1}$, Mehmet OZASLAN ${ }^{2}$, Mehmet YILMAZ ${ }^{3}$, I. Didem KARAGOZ ${ }^{2}$, \\ Ibrahim H. KILIC ${ }^{2}$, Ebru TEMIZ ${ }^{1}$, Beyhan CENGIZ ${ }^{4}$ \\ ${ }^{1}$ Gaziantep University, Faculty of Medicine, Department of Medical Biology, Gaziantep \\ ${ }^{2}$ Gaziantep University, Faculty of Science, Department of Molecular Biology, Gaziantep \\ ${ }^{3}$ Gaziantep University, Faculty of Medicine, Department of Hematology, Gaziantep \\ ${ }^{4}$ Gazi University, Faculty of Medicine, Department of Medical Genetics, Ankara, TURKEY
}

\begin{abstract}
Acute Myeloid Leukemia (AML) is a hematopoietic stem cell disorder. Many of the tumor development steps are processes regulated by $\mathrm{Ca}^{2+}$ dependent signaling pathways found in tumor growth. Calcium channels, which can be blocked by pharmacological agents such as verapamil, are important in the regulation of intracellular $\mathrm{Ca}^{2+}$ homeostasis. The failure to stop cell cycle and to achieve programmed cell death are the most important factors in AML or other types of cancers and are considered to be the real cause of cancer. Our aim in this study was to investigate the effect of verapamil on apoptosis and cell cycle in AML cell line, HL-60, using flow cytometry. The effective dose of verapamil was determined as $50 \mathrm{mg} / \mathrm{ml}$ by MTT method, and was applied to HL-60 cells, subsequently, they were assessed for apoptosis and cell cycle. After $50 \mathrm{mg} / \mathrm{ml}$ of verapamil application, apoptotic cell ratio was found to be $77.7 \%$ after 24 hours $(p<0.05)$. In cell cycle analysis, the ratio of diploid cells decreased in $\mathrm{G} 1$ phase and increased in $\mathrm{S}$ phase, and the ratio of aneuploid cells decreased in G1 phase $(p<0.05)$ and increased in $S$ phase $(p>0.05)$ in verapamil-untreated group when compared to verapamil-treated group.
\end{abstract}

Keywords: AML, Verapamil, Cell cycle, Apoptosis

\section{ÖZET}

AML (HL-60) Hücre Hattında Kalsiyum Kanal Blokeri Verapamilin, Hücre Döngüsü ve Apoptosiz Üzerine Etkisi

Akut yyeloid lösemi (AML) bir hematopoetik kök hücre hastalığıdır. Tümör gelişimi adımların çoğu tümör büyümesinde işleyen Ca ${ }^{+2}$ bağımlı sinyal yolakları tarafından düzenlenen süreçlerdir. Verapamil gibi farmakolojik ajanlar tarafından bloke edilebilir kalsiyum kanalları, hücre-içi $\mathrm{Ca}^{+2}$ homeostazının düzenlenmesinde önemlidir. AML veya diğer kanser türlerinde en önemli faktörler olarak hücre döngüsünü durdurmada ve programlanmış hücre ölümünü sağlamadaki hata, kanserin gerçek nedeni olarak kabul edilir. Bu çalışmadaki amacımız akım sitometri kullanarak AML hücre hattında, HL-60, apoptoz ve hücre döngüsüne Verapamil'in etkisini araştırmaktır. Verapamil'in etkili dozu MTT metodu ile 50 mg/ml olarak belirlendi, HL-60 hücrelerine uygulandı ve apoptoz ve hücre döngüsü açııından değerlendirildi. 50 mg/ml Verapamil uygulaması sonrasında, 24 saatin sonunda apoptotik hücre oranı \%77.7 olarak saptanmıştır $(p<0.05)$. Hücre döngüsü analizinde, Verapamil uygulanmamış grupta Verapamil uygulanmış gruba göre, diploid hücrelerin oranı G1 fazında azalmış ve $S$ fazında artmış ve aneuploid hücrelerin oranı G1 fazında azalmış $(p<0.05)$ ve S fazında artmıştır ( $p>0.05)$.

Anahtar Kelimeler: AML, Verapamil, Hücre siklusu, Apopitozis 


\section{INTRODUCTION}

Although many cancer-related studies have been conducted, there are no definitive treatment yet. Acute Myeloid Leukemia (AML) is a hematopoietic (blood-forming) stem cell disorder and a disease characterized by the transformation of myeloid-derived precursor blood cells, transforming to mature blood cells during hematopoiesis process, to clonal proliferating neoplastic cells losing their ability to differentiate. ${ }^{1}$ Intracellular $\mathrm{Ca}^{2+}$ is highly critical in order to maintain the normal function of cell. Changes in the level of intracellular $\mathrm{Ca}^{2+}$ cause certain alterations in cell death, apoptosis and meiotic cell cycle. ${ }^{2}$ Calcium channel blockers such as verapamil (CCB) generally block voltagegated calcium channels and inhibit calcium entry into the cell from outside the cell. ${ }^{3}$

It is observed that verapamil stops cell cycle and protect the cell against apoptosis when it is applied to the normal cells at certain doses. Verapamil is shown to inhibit in vitro growth of meningioma and leukemia cells. ${ }^{4}$ The number and incidence of spontaneous metastasis decreases as a result of verapamil treatment. The sizes of metastatic nodules were reduced in mice administered verapamil treatment. Verapamil provides this reduction by causing cytotoxic effects on the proliferative capacity of metastatic nodules. In addition to these effect of verapamil, it is also known that it inhibits p-glycoprotein by suppressing MDR gene activity and causes suppression of the proliferation of cancer stem cells via this effect. Another interesting feature of verapamil is that it increases the diameter of pulmonary blood vessels. Tumor cells suppress lung microcirculation in metastatic cascade. Capillary vessel diameters increase with the inhibitory effect of verapamil. Verapamil is an agent having unexpected anti-invasive and anti-metastatic properties. It also has an inhibitory effect on tumor progression with its vasodilatory property. ${ }^{5}$ In this study, we aimed to investigate whether verapamil stops the cell in the mitotic phase, and at which stage it occurs if it stops by giving verapamil to acute myeloid leukemia cell line, HL-60, in certain doses. In addition, to show whether it has a protective effect by reducing tissue damage in ischemia and reperfusion study.

\section{MATERIALS and METHODS}

All chemicals and plastics used in our study were purchased in the scope of SRP project (Project no: FEF.14.10). Acute myeloid leukemia cell line (HL60) was purchased from ATCC. The study was conducted in the Laboratory of Molecular Genetics and Hematology at the Faculty of Medicine, Gaziantep University.

\section{Chemical Compounds and Kits}

RPMI-1640 cell growth medium, fetal calf serum (FCS), Hank's Balanced Salt Solution (HBSS), verapamil hydrochloride, Dimetil sülfoksit (DMSO) and MTT ((3-[4, 5-dimethylthiazol-2-yl]-2, 5 diphenyl tetrazolium bromide) were purchased from Sigma-Aldrich company (St. Louis, MO, USA). Penicillin/streptomycin $(10.000 \mathrm{U} / 10.000 \mu \mathrm{g} / \mathrm{ml})$ was purchased from Thermo Fisher Scientific company (MA, USA). Annexin-V PE Apoptosis Detection Kit I and Cell Cycle Test Plus DNA Reagent Kit were purchased from Becton Dickinson company (MD, USA).

\section{Cancer Cell Lines and Cell Culture}

After the stock containing HL-60 cells was taken out of the nitrogen tank $\left(-196^{\circ} \mathrm{C}\right)$ it was melted rapidly in a $37^{\circ} \mathrm{C}$ water bath, thereafter it was divided into centrifuge tubes containing $5 \mathrm{ml}$ of medium (10\% FCS, $1 \%$ penicillin/streptomycin, RPMI1640 ) and was placed into an incubator (Sanyo IR Sensor, Sanyo Canada) at $37^{\circ} \mathrm{C}$ and $5 \% \mathrm{CO}_{2}$. Cell cultures were put into RPMI-1640 with 10\% FCS. HL-60 cells were grown in suspension culture medium containing $50 \mathrm{ml}$ of RPMI-1640 medium with $10 \% \mathrm{FCS}$ and $1 \%$ penicillin/streptomycin at $37^{\circ} \mathrm{C}$ and $5 \% \mathrm{CO}_{2}$ inside the incubator. ${ }^{6}$

\section{Assessment of Cell Viability}

Cell density was determined by MTT assay based on spectrophotometric measurement methods. After adjusting $4 \times 10^{5} \mathrm{HL}-60$ cells in $1 \mathrm{ml}, 500 \mu \mathrm{l}$ of it was placed into 24-well plates used for MTT assay. When HL-60 acute myeloid cancer cell culture reached to $70-80 \%$ cell density in 24 well plates, they were incubated in RPMI-1640 medium with FCS for 24 hours and then incubated in different 


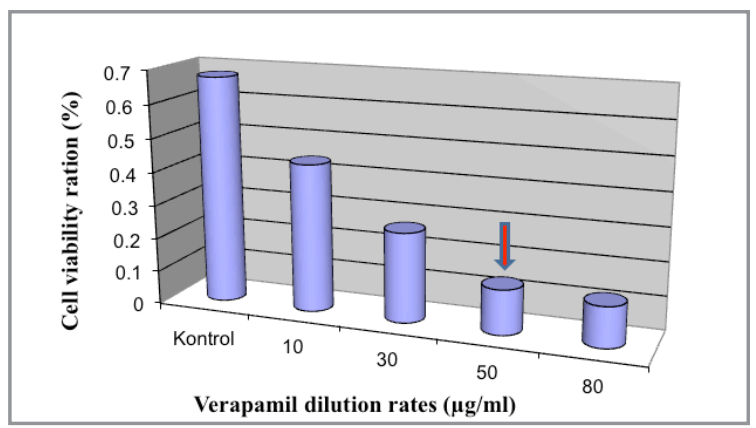

Figure 1. The effective dilution rates of verapamil. The cells were incubated with different dilutions $(10,30,50,80 \mu \mathrm{g} / \mathrm{ml})$ of verapamil for 24 hours. The cells incubated in SF (saline solution) were used as positive control. It was seen that the half of the cells dies with $50 \mu \mathrm{g} / \mathrm{ml}$ of verapamil.

dilutions $(10,30,50$ and $80 \mu \mathrm{g} / \mathrm{ml})$ of verapamil for 24 hours. Verapamil-untreated group was determined as control group. Cells were taken into 1.5 $\mathrm{ml}$ micro-centrifuge tubes and were centrifuged at $2000 \mathrm{rpm}$ for 4 minutes. The supernatant was removed and the underlying pellet was washed with $500 \mu \mathrm{l}$ of HBSS. After centrifugation at 2000 rpm for 4 minutes, the supernatant was removed. The resulting cell pellet was dealt with $500 \mu \mathrm{l}$ of MTT dye and left to stand at $37^{\circ} \mathrm{C}, 5 \% \mathrm{CO}_{2}$ for 30-45 minutes. The supernatant was removed with the centrifugation at $2000 \mathrm{rpm}$ for 4 minutes. The pellet was dissolved with DMSO. Pipetting was done to each well of 96 well-plate from $100 \mathrm{ml}$ of the samples and measurement was realized with a spectrophotometer at $550 \mathrm{~nm}$ wavelength. The effective dose of verapamil was determined as $50 \mu \mathrm{g} /$ $\mathrm{ml}$ (Figure 1). The effective dose of verapamil was used in our cell cycle and apoptosis studies. ${ }^{7}$

\section{Assessment of Cell Cycle and Apoptosis}

$50 \mathrm{mg} / \mathrm{ml}$, determined as the effective dose, of verapamil was applied for 24 hours when cell count reached to $10^{5}-10^{6}$ cells $/ \mathrm{ml}$. The cells were then washed 2 times with cold PBS. $500 \mu \mathrm{l}$ of binding solution inside Apoptosis Detection Kit was added on top of the remaining residue after the liquid on the precipitate was discarded. $100 \mu \mathrm{l}$ of this suspension was placed in a $5 \mathrm{ml}$ falcon tube. $5 \mu 1$ of ready-to-use Annexin V-PE and 7AAD solutions were added on it. The solution was stirred gently.
Tubes were incubated for 15-20 min on ice in the dark. They were centrifuged at $1500 \mathrm{rpm}$ for 5 min after the incubation. The top supernatant was poured and $500 \mu \mathrm{l}$ of cold binding solution onto the cells and mixed. Cell samples were analyzed in Navios Flow Cytometry (Beckman Coulter, Miami, FL, USA).

\section{Evaluation of Cell Cycle}

The cells in suspension were washed with buffer solution and the supernatant was decanted after centrifugation at $1500 \mathrm{rpm}$ for $5 \mathrm{~min}$. This process was repeated 2 times. $250 \mu \mathrm{l}$ of solution A (trypsin buffer, BD Pharmingen, MD, USA) was added onto the pellet in each tube and stirred lightly. Tubes were shaken gently by hand, not using vortex. Tubes were incubated with the solution A at room temperature $\left(20-25^{\circ} \mathrm{C}\right)$ for $10 \mathrm{~min}$. Then, $200 \mu 1$ of solution B (trypsin inhibitor and RNase buffer, BD Pharmingen, MD, USA) was added to each tube and again stirred gently by hand. After solution $\mathrm{B}$ addition to tubes, they were incubated at room temperature for $10 \mathrm{~min}$. Then, $200 \mu \mathrm{l}$ of cold $\left(2-8^{0} \mathrm{C}\right)$ solution $\mathrm{C}$ (BD Pharmingen, MD, USA) was added to the tubes and they were incubated at $+4^{0} \mathrm{C}$ in the dark for $10 \mathrm{~min}$. At the end of the incubation period, the samples were passed through Navios Flow Cytometry (Beckman Coulter, Miami, FL, USA), DNA analyzes were performed using ModFit program and the effect of the drug was evaluated. ${ }^{8}$

\section{RESULTS}

The apoptotic cell ratio of cultured verapamiluntreated HL-60 cells was examined. Verapamiluntreated HL-60 cells were used as controls. The ratio of the number of apoptotic cells in the total cell number was found to be $0.4 \%$ in verapamil-untreated HL-60 cells (control group) at the end of 24 hours (Figure 2). $50 \mathrm{mg} / \mathrm{ml}$ verapamil was given to cultured HL-60 cells and the ratio of the number of apoptotic cells in the total cell number was found to be $77.7 \%$ at the end of 24 hours. Verapamil $(50 \mathrm{mg} /$ $\mathrm{ml}$ ) increased the ratio of apoptotic cells compared with control cells in statistically significant manner after 24 hours $(\mathrm{p}<0.001)$ (Figure 3$)$. In cell cycle 


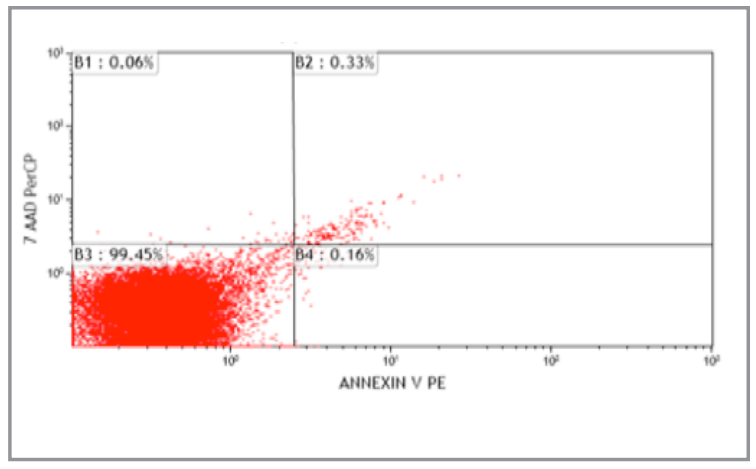

Figure 2. Apoptotic cell rates of verapamil-untreated HL-60 cells

analysis, diploid cell ratio in control cell group (verapamil-untreated) was $70.02 \%$ in G1 phase while diploid cell ratio in G1 phase in DNA analysis of HL-60 cells in $50 \mathrm{mg} / \mathrm{ml}$ verapamil-treated group after 24 hours was changed to $21.59 \%$. A statistically significant decrease was observed $(\mathrm{p}<0.05)$. While diploid cell ratio in $\mathrm{S}$ phase of the control cell group was around $18.18 \%$, diploid cell ratio in S phase in DNA analysis of HL-60 cells treated with verapamil for 24 hours increased to $67.21 \%$ and this was a significant difference $(\mathrm{p}<0.05)$. This ratio was $12.16 \%$ in $\mathrm{G} 2$ / $\mathrm{M}$ phase of the control group while it was $11.20 \%$ in verapamil-treated group and there was no significant difference (Table 1, Figure 4). The aneuploid cell ratio of control cell group in G1 phase was $43.42 \%$ while aneuploid cell ratio in G1 phase in the DNA analysis of HL-60 cells treated with verapamil, of which IC 50 value (viability value) was determined as $50 \mathrm{mg} /$ $\mathrm{ml}$, for 24 hours changed to $60.98 \%$ and this increase was statistically significant $(\mathrm{p}<0.05)$. Aneuploid cell ratio in $\mathrm{S}$ phase in the control cell group was around $50.46 \%$ while aneuploid cell ratio in $\mathrm{S}$ phase in the DNA analysis of HL-60 cells treated

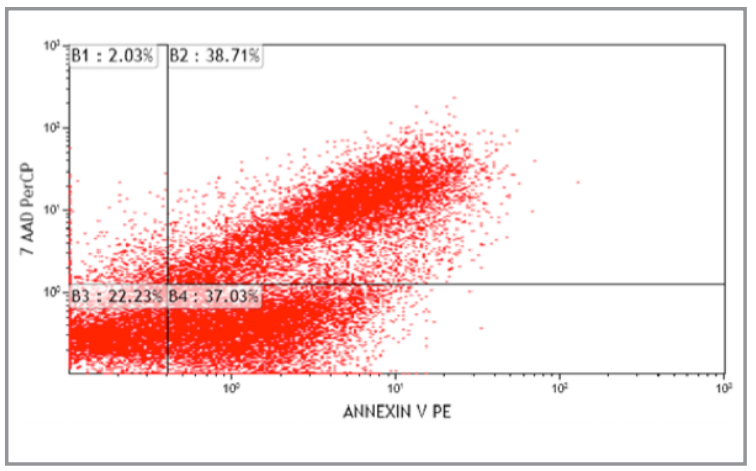

Figure 3. Apoptotic cell rates of verapamil-treated HL-60 cells

with verapamil for 24 hours was $37.26 \%$ and this difference was not significant ( $p>0.05$ ). Aneuploid cell ratio in G2 / M phase in the control group was $0 \%$ and $3.03 \%$ in verapamil-treated group, and the difference was not significant. Results were analyzed by Mann Whitney U test.

\section{DISCUSSION}

Acute Myeloid Leukemia (AML) is a blood disease, as explained at the beginning of the subject. This disease seen in individuals at advanced ages is a pathological condition resulting from the loss of control of cell growth and proliferation after especially de novo mutations occurring on the genetic material, DNA, of stem cells taking role in hematopoietic system. ${ }^{1,9}$ Is a disease usually seen in 3-5 out of 100,000 adults. ${ }^{10}$ AML is a condition that occurs as a result of the fact that cell cycle cannot be controlled, same with all cancers. Cell division is physiologically divided into five phases. Among them, G0 phase is known as the cell dormancy. Cells cannot perform physiological events associated with cell division at this stage. G1 phase fulfills the function of cell growth. S phase is the

Table 1. Diploid cell ratios in verapamil-untreated (control) ve verapamil-treated cell groups

\begin{tabular}{|lll}
\hline Diploid cell ratios & $\begin{array}{l}\text { Verapamil-untreated } \\
\text { (Control) }\end{array}$ & Verapamil-treated \\
\hline G1 & $70.02 \%$ & $21.59 \%^{*}$ \\
S & $18.18 \%$ & $67.21 \%{ }^{*}$ \\
G2 & $12.16 \%$ & $11.20 \%$ \\
\hline
\end{tabular}

${ }^{*} p<0.05$ shows statistically significant difference 


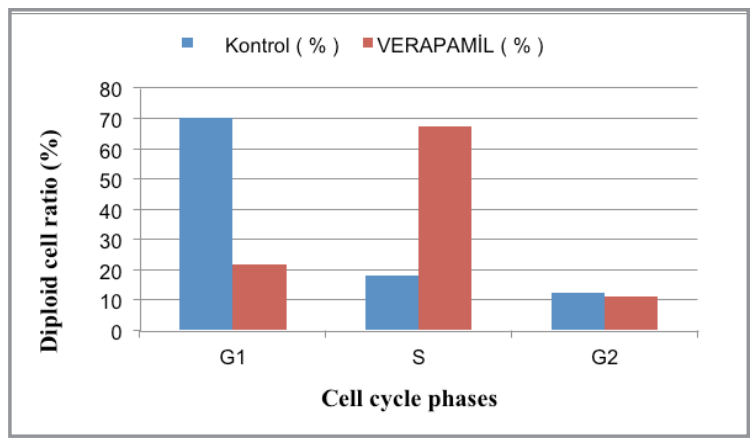

Figure 4. Diploid cell ratios in verapamil-untreated (control) and verapamil-treated cell groups

synthesis phase, where DNA self-replication and synthesis are seen for cell division. The G2 phase is the correction phase of errors occurring in the cells during the duplication. $\mathrm{M}$ phase comes after this phase and, controls and performs all stages of mitosis. ${ }^{11}$

There are some important molecules involved in cell division. The place of $\mathrm{Ca}^{2+}$ is special among them. $\mathrm{Ca}^{2+}$ acts as a second messenger. In addition, it is involved in providing the energy needed by the cell. Its role in nerve conduction is also known. Apart from this, It binds to and activates several hormones and molecules. Moreover, it is reported that it has a stimulating effect in the division of leukocytes. When the amount of $\mathrm{Ca}^{2+}$ in the blood rises to the level of $15 \mu \mathrm{M}$, it serves as stimulus for the division of leukocytes. ${ }^{12}$ Calcium is reported to take key role in the end of G1 phase, transition to $\mathrm{S}$ phase, entry into $\mathrm{M}$ phase and the completion of this phase in the cell cycle. It was found in the study performed on L929 cell lines that cell cycle arrest occurred as a result of verapamil administration. This arrest seen in mitosis was as a result of the fact that verapamil blocked calcium channels and inhibited calcium entry into the cell. ${ }^{13}$ In accordance with these findings, the ratio of the cells in $\mathrm{S}$ phase was very high in verapamil-treated group as a result of our work. It is the effect caused by $\mathrm{Ca}^{+2}$ molecules released from the endoplasmic reticulum into the cytoplasm inside the cell. $\mathrm{Ca}^{2+}$ is needed to be taken from outside the cell due to the fact that the level of $\mathrm{Ca}^{2+}$ required for passing to $\mathrm{G} 2$ / M phase after $\mathrm{S}$ phase cannot be provided inside the cell. As a result of blockage of this way

\begin{tabular}{|lcl|}
\hline \multicolumn{2}{|l|}{$\begin{array}{l}\text { Table 2. Aneuploid cell ratios in verapamil-untreated (control) } \\
\text { and verapamil-treated cell groups }\end{array}$} \\
\hline Aneuploid & Control & Verapamil \\
\hline G1 & $43.42 \%$ & $60.98 \%{ }^{*}$ \\
S & $50.46 \%$ & $37.26 \%$ \\
G2 & $0.00 \%$ & $3.03 \%$ \\
\hline & & \\
\hline
\end{tabular}

by verapamil, there was no significant change in $\mathrm{G} 2$ / M phase due to insufficient $\mathrm{Ca}^{2+}$ amount. One of the reasons that early apoptosis is also seen in Annexin V staining is that Annexin V is a receptor on the cell membrane. Annexin $\mathrm{V}$ needs to be activated for entry of extracellular $\mathrm{Ca}^{2+}$ molecules, needed by the cell, into the cells and thereupon it causes misinterpretation of early apoptosis. Late apoptosis is apoptosis occurring due to the inability to provide $\mathrm{G} 2$ / M phase transition after S phase of the cell. In a study performed on rat eggs in the culture medium, it was detected that $50 \mu \mathrm{M}$ of verapamil-treated cells led to apoptosis. ${ }^{2}$ In our study, it was observed that when verapamil was applied to HL-60 cells in culture medium at the same dose, the cells entered into late apoptosis. Here, another important point is apoptosis stimulation occurring due to the fact that the cells in S phase don't pass to G2 / M phase. This stimulation process showed that the cell leads to apoptosis by using Caspase 3 pathway due to lack of sufficient amounts of $\mathrm{Ca}^{2+}$, which is needed for the formation of cyclin D-CDK4 (cyclin-dependent kinase 4) required for cell division, in the cell cytoplasm as a result of division signals produced in HL-60 cells, an AML cell line. ${ }^{12}$

It has been reported in some studies that cancer develops over time depending on the dose in adults who use verapamil in their lifetime. Another study was conducted on cancer stem cells and they consequently published that verapamil led the cell to apoptosis. ${ }^{14,15}$ Although these two different results seem not to overlap much with the result in our study, the response of a pathological cell, such as 


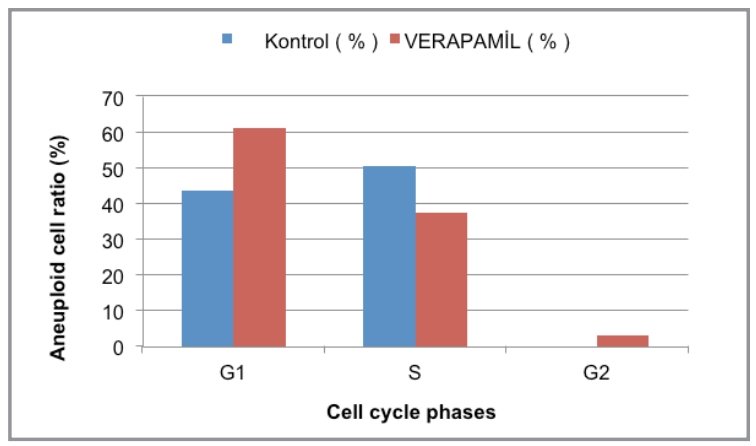

Figure 5. Aneuploid cell ratios in verapamil-untreated (control) ve verapamil-treated cell groups

cancer cell, to verapamil would not be the same with a normal cell. The study conducted on humans is observational. The role of several tissues and organs in drug metabolism has been omitted in relation to patient's drug usage, dose, the response of normal cells and most importantly, the environment where the drug is metabolized. A previous study found that the cells escaped from apoptosis when verapamil was applied in the absence of $\mathrm{Ca}^{+2}$ and the presence of 25-hydroxycholesterol in the cell culture medium. ${ }^{16}$ Our study showed that apoptosis increased as a result of the addition of verapamil to the cancer cell cultures. Thus, the combinatorial administration of drugs used and synchronizing agents like verapamil before the treatment administration or after the determination of cell cycle phases in the cancer types insensitive to the treatment and the detection of sensitivity to apoptosis are important to increase their effect. The data obtained in the study will be useful to evaluate the research in this way.

\section{CONCLUSION}

Check points are involved in the regulation of the transition between cell cycle phases. ${ }^{14}$ The first of the main control point is DNA damage sensor in G1 / S transition. While the cells damaged between early and mid-G1 phases stalls in G1 phase, the cells damaged in late $\mathrm{G} 1$ phase continue to the $\mathrm{S}$ phase. ${ }^{17,18}$ The increase in the cell count in $\mathrm{S}$ phase when compared to the control group suggested that verapamil used led the cells to apoptosis by closing calcium channels, inhibiting $\mathrm{Ca}^{2+}$ entry into cells and stopping transition to G2 phase and cell divi- sion. Thus, the cell division phases' rates obtained with the synchronization of verapamil stalling the cells in G1 / S transition are consistent with these information. Our study may contribute to the development of new agents effective in increasing the efficacy in the treatment of cancer, prevention of DNA damage and inhibition of the development of some drugs' resistance. In addition, would provide a new perspective to induce the selective death of the tumor cells and constitute a resource for further molecular studies to be performed.

\section{REFERENCES}

1. Ares M, Pörn-Ares M, Thyberg J, et al. $\mathrm{Ca}^{2+}$ channel blockers verapamil and nifedipine inhibit apoptosis induced by 25-hydroxycholesterol in human aortic smooth muscle cells. J lipid Res 38: 2049-2061, 1997.

2. Balci A, Sahin Fl. Gossypol induced apoptosis in the human promyelocytic leukemia cell line HL 60. Tohoku J Exp Med 189: 51-57, 1999.

3. Beiderbeck-Noll A, Sturkenboom M, Van Der Linden P, et al. Verapamil is associated with an increased risk of cancer in the elderly: the Rotterdam study. Eur J Cancer 39: 98-105, 2003.

4. Tadeusz R, Agnieszka W. Current and Emerging Therapies for Acute Myeloid Leukemia. Clin Ther 31: 2349-2370, 2009.

5. Roderick HL, Cook SJ. $\mathrm{Ca}^{2+}$ signalling checkpoints in cancer: remodelling $\mathrm{Ca}^{2+}$ for cancer cell proliferation and survival. Nat Rev Cancer 8: 361-375, 2008.

6. Chaube S, Tripathi A, Khatun S, et al. Extracellular calcium protects against verapamil-induced metaphase-II arrest and initiation of apoptosis in aged rat eggs. Cell Biol Int 33: $337-$ 343, 2009.

7. Cheng S, Wu Q, Yang F, et al. Influence of DL- $\beta$-hydroxybutyric acid on cell proliferation and calcium influx. Biomacromolecules 6: 593-597, 2005.

8. Yedjou GC, Moore P, Tchounwou P. Dose- and time-dependent response of human leukemia (HL-60) cells to arsenic trioxide treatment. Int J Environ Res Public Health 3: 136-140, 2006.

9. Ghaffari S. Oxidative stress in the regulation of normal and neoplastic hematopoiesis. Antioxid Redox Signal 10: 19231940, 2008.

10. Durmaz R, Deliorman S, Uyar R, et al. The effects of anticancer drugs in combination with nimodipine and verapamil on cultured cells of glioblastoma multiforme. Clinical Neurol Neurosurg 101: 238-244, 1999.

11. Elledge SJ. Cell cycle checkpoints: preventing an identity crisis. Science 274: 1664-1672, 1996.

12. Estey E, Döhner H. Acute myeloid leukaemia. Lancet 368: 1894-1907, 2006. 
13. Hartwell LH, Weinert TA. Checkpoints: controls that ensure the order of cell cycle events. Science 246: 629-633, 1989.

14. Murray A, Hunt T. The cell cycle: an introduction. New York, W.H. Freeman and Co, 1993: 153-156.

15. Oktem G, Serap U, Uysal A, et al. Kanser kök hücresi ve Notch yolalaginda umut veren ortak embriyonik dönem inhibisyonu. Cerrahpasa Med J 40: 23-27, 2009.

16. Redner A, Lanzkowsky P. Leukemias. Manual of Pediatric Hematology and Oncology. 4th edition. San Diego, Elsevier Academic Press, 2005: 415-52.

17. Shipley JL, Butera JN. Acute myelogenous leukemia. Exp Hematology 37: 649-658, 2009.

18. Nagashima H, Goto T. Calcium channel blockers verapamil and diltiazem impaired rubraoxin B-casused toxicity in HL60 Cells. Toxicol Lett 118: 47-51.

\section{Correspondence}

Gülper NACARKAHYA

Gaziantep Üniversitesi Tip Fakültesi

Tibbi Biyoloji Bölümü

GAZIANTEP / TURKEY

Tel: (+90-342) 3606060 / 77480

e-mail: gulperkoyuncu@gmail.com 